\title{
Hypertension due to renal artery stenosis
}

\author{
Husein Albar, Haeriah Rahman, Syarifuddin Rauf \\ Department of Child Health, Medical School, University of Hasanudin, Wahidin Sudirohusodo Hospital, \\ Ujung Pandang, Indonesia
}

\begin{abstract}
A case of a 12-year-old boy with renal artery stenosis as a cause of hypertension is presented. The diagnosis of renal artery stenosis was established based on the bruit heard over costovertebral angle and the increased plasma renin secretion, and further confirmed by angiogram finding. The detection of bruit, either on the abdomen or costovertebral angle, in association with hypertension should initially lead to the consideration of the presence of renal artery stenosis. [Paediatr Indones 2001;41:60-63]
\end{abstract}

Keywords: renal artery stenosis, hypertension

HYPERTENSION IS DEFINED AS AN AVERAGE SYSTOLIC AND diastolic blood pressure greater than 95th percentilc for age and sex measured on at least three separate occassions. ${ }^{1}$ Hypertension associated with renal diseases is commonly found in children. Previous reports stated that most sccondary hypertension in childhood and adolescence is duc to renal and renovascular disorder whereas other causes, including coarctation of the aorta, pheochromocytoma, Cushing's syndrome, and primary aldosteronism, accounts for only a minority of cases, ${ }^{2,3}$ The prevalence of renal parenchymal diseases as the underlying causes of secondary hypertension in children adolescence is higher (60 to $80 \%)^{3}$ than those of renovascular lesions (10\% to $24 \%) .4$

Since hypertension may occasionally be an acute emergency in children because of the impact of scverely elevated blood pressurc on vital organ systems resulting in hypertensive encephalopathy, symptomatic pulmonary edema, cardiovascular failure and

Correspondence: Husein Albar, MD, Department of Child Health, Medical Scool, University of Hasanuddin, Makassar, Indonesia. hypertensive retinopathy, ${ }^{1.8}$ it should be treated appropriately without delay for the stabilization of the blood pressure. The purpose of this report is to describe a case of renal artery stenosis as the underlying cause of hypertension in a 12-year-old boy.

\section{Report of the case}

A 12-year-old boy was referred to the hospital on July 28,1997 with a diagnosis of acute glomerulonephritis. The patient complained of having a 6-month history of bifrontal headache, nausea, and vomiting. Periorbital and pretibial edema appeared 1 month before hospitalization. There was no history of urinary tract infection and other symptoms were unre-markable.

Physical examination revealed a well-nourished child with body weight of $25 \mathrm{~kg}$ and height of $126 \mathrm{~cm}$. Rectal temperaturc, pulse rate, respiratory rate, and blood pressure were $37.4^{\circ} \mathrm{C}, 120$ per minute, 28 per minute, and $170 / 120 \mathrm{mmHg}$ (upper extremities) and 180/120 mmHg (lower extremities), respectively. Periorbital and pretibial edema were absent. Pertinent physical findings included normal heart and lungs, bruit on the costovertebral angle and absence of visual disturbances. Others were unremarkable. 
Laturatory exannination documented normal routine hlood data and urinalysis, and urine culture yiclded nu growth of pathogenic hacteria. Blood ureum and creatinine were $11.5 \mathrm{mg} / \mathrm{dl}$ and $0.96 \mathrm{mg} /$ $\mathrm{dl}$, respectively. Creatininc clearance was $86 \mathrm{ml}$ per minute per $1.73 \mathrm{~m}^{2}$. Albumin, globulin, and cholesterol levels were normal. Urinary excretion per 24 hours was $1500 \mathrm{ml}$.

Chest $\mathrm{X}$-ray and electrocardiogram were normal. The initial clinical impression was hypertension due to acute nephritic syndrome and suspicion of renal artety stenosis. The patient was advised to have a total bed rest and low salt diet. Scr-ap-es and furoscmide werc given orally with a goosd clinical response.

\section{Clinical course}

On the 4th day of hospitalization, carpopedal spasm developed. His blood pressure was $140 / 100 \mathrm{mmHg}$ (upper extremities).Serum electrolytes showed sodium $137 \mathrm{mEq} /$, potassium $2.1 \mathrm{mEq} / \mathrm{l}$, chloride $88 \mathrm{mE} / \mathrm{l}$, and calcium $6.7 \mathrm{mg} / \mathrm{dl}$. The patient was given Elkana (a preparation containing calcium phosphate, calcium lactate), potassium chloride, and Ser-ap-es (rescrpin, hydralazine, hydrochlorothiazide) orally t.i.d. Furosemide was discontinued. Other hematologic data showed C3 complement of $145 \mathrm{mg} / \mathrm{dl}$, ASTO $<200$ IU. Urinalysis was normal.

On the 5 th day from admission, carpopedal spasm disappeared. Cardiologic evaluation showed normal heart size. There was no evidence of retinopathy. On the 9th day of follow-up, the patient complained of headache, nausea, and vomiting. He becrame unconscious and general convulsion developed. His blood pressure rosc up to $170 / 120 \mathrm{mmHg}$ (upper extrcmities). He, thereforc, was diagnosed as having hypertensivc encephalopathy and treated with parenteral clonidine and furoscmide. Serum electrolytes showed calcium $9.9 \mathrm{mg} / \mathrm{dl}$, potassium $3.5 \mathrm{mEq} /$, sodium 137 $\mathrm{mEq} / \mathrm{l}$, and chloride $98 \mathrm{mEq} / \mathrm{l}$. Peripheral plasma renin activity at supine position was $26.64 \mathrm{ng}$ per $100 \mathrm{ml}$ per hour. Renal ultrasonogram showed a normal left kidney and a small right kidney measuring $8.5 \times 4 \mathrm{~cm}$ and $5 \times 2 \mathrm{~cm}$, respectively (Figure 1). An intravenous pyclogram showed bilatcral equal visualization with right kidncy shadow smaller than the left. A renal computed tomogram using contrast medium revcaled a normal left kidncy and a small right kidney (see Figure 2).
On the 10th day of hospitalization, all signs and symptoms of hypertcnsive encephalopathy disappeared. $\mathrm{Hi}_{\mathrm{s}}$ blood pressure decreased to $160 / \mathrm{l00} \mathrm{mmHg}$. Parenteral clonidine and furosemide was discontrnued and oral captopril $12.5 \mathrm{mg} \mathrm{t.i.cl}$. was starred. On the subsequent follow-up, the blood pressure decreased to $120 / 80 \mathrm{mmHg}$. The patient did not complain of headache, nausea, and vomiting. The bruit remained heard on the costovertebral ingle. An alxlominal and renal arteriogram demonstrated a normal right kid. ney and a small left kidney with renal artery stenosis associated with a mild narrowing of the abdominal aorta. (Figure 3).

By the 20th day of hospitalization, the patient rematined in a gexd general condition. His blusel prow. sure was stahle at $120 / 80 \mathrm{mmH}_{\text {p. He was then re }}$ ferred to the [Department of Radieslegy: Medical School, University of Indonesia, Jakirta fur percutas. neuus transarterial angiography (PTA). (Figure 4).

\section{Discussion}

Acutc renal parenchymal disease is the most commun causc of secondary hypertension in children.' In acute poststreptococcal glomerulonephriris, $40 \%$ to $50 \%$ or more hospitalized patients are hyperrensive, a quarter of thesc severely so.' Despite the evidence of bruit on his costovcrtebral angle, we suspected sur patient of suffering from acute poststreptococcal glomerulonephritis, bccause of signs and symptoms of hypertension, and history of edema. Morcover, acute poststrcptococcal glomcrulonephritis is the most frequent cause of hospitalized patient with hypcrtension in our Division of Pediatric Nephrology, Dr. Wahidin Sudirohusodo Hospital, Ujung Pandang.

It is evident that bedside Scr-ap-es and furosemide, as the regimen frequently used for hypertension for our patients with acute poststrcptococcal glomerulonephritis, failed to decrease the elevated blood pressure in this casc, and other findings did not confirm the diagnosis of acute poststreptococcal glomcrulonephritis. We thcrefore performed the modified three-stage investigations, ${ }^{6}$ to find out other causes of rcnal hypertension in our patient. The first test carried out comprised of urinalysis, urine culture, renal function test, intravenous pyelography, and peripheral plasma renin activity. Since the peripheral plasma renin level was remarkably high, we therc- 


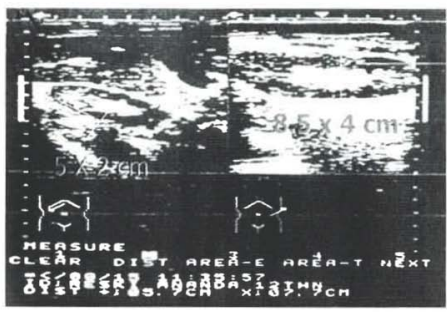

Figure 1. Renal ultrasonogram showed a small right kidney measuring $5 \times 2 \mathrm{~cm}$

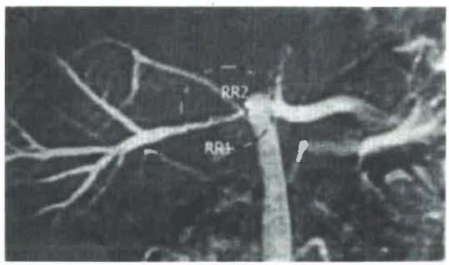

Figure 3. Penal arteriogram demonstrated the stenosis of the main branch of right renal artery (RR1) circle.

fore, performed the subsequent tests including renal ultrasonography, renal arteriography, and renal computed tomography to look for renovascular lesions.

The renal ultrasonogram (Figure 1) and computed tomogram (Figure 2 ) revealed a normal left kidney and a small right kidney. The abdominal and renal arteriogram (Figure 3) demonstrated a normal right kidney and a small left kidney with renal artery stenosis associated with mild narrowing of the abdominal aorta. These findings confirmed the diagnosis of renal artery stenosis as the cause of hypertension.

It is stated that abdominal bruit heard in children with hypertension suggests renal artery stenosis as a cause. However, of 45 children reported with normal findings on renal arteriogram, $13 \%$ has $a b$.

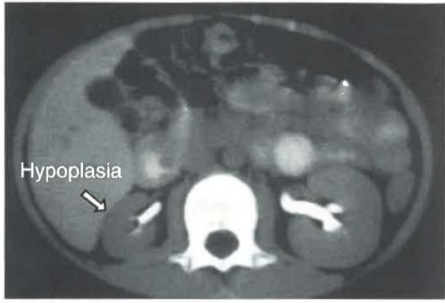

Figure 2. Renal CT using contras medium revealed the right kidney was smaller the left (arrow)

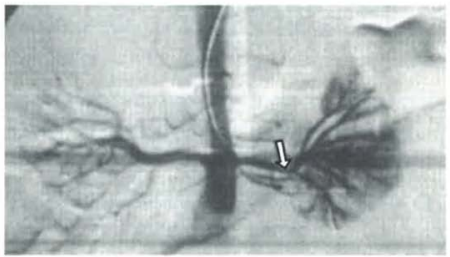

Figure 4. After PTA, the main branch of right renal artery appeared to dilate RR1, arrow.

dominal bruit and 19 (30\%) out of 63 children with documented renal artery stenosis have abdominal bruit. ${ }^{4} \mathrm{~A}$ bruit may also he occasionally heard over the costovertebral anglc. ${ }^{7}$ The bruit in our case was only heard over the costovertebral angle.

Hypertensive encephalopathy develops preferentially with an acute rise in blood pressure. Seizures either focal or general sccm to occur more frequently in children than adults and are regularly accompanied by loss of consciousness. ${ }^{8.9}$ Our patient had a general seizure accompanied by disorder of consciousness. These symptoms disappeared within a few minutes after treatment but complete recovery was achieved within 24 hours and his blood pressure was back to normal within 48 hours. 
Hypertension in our patient seemed to result from an overproduction of renin (known to be the main cause of renovascular hypcrtension) 9 as the blond pressurc decreased to normal within a few hours after captopril therapy. After the PTA was performed, the right renal artery stenosis appeared to dilate (RR1). It seems that if bruit is heard on the atdomen or cos. tovertebral angle in children with hypertension, then renal artery stenosis as a cause of hypertension should be initially considered.

\section{References}

1 National High Blood Pressure Education Proyram Working Group on Hypertension Control in Children and Adolescents. Upiate on the task force report on high blowd pressure in children and actulescent. Pediarrics 1996; 98:649. 57.
2 Ingelfinger JR. Hlypertension. In: Edelmann CM, Benstein J. editors. Pedintric kidney disease. 2 nd ed. Boston: Little Bro,wor and $C_{1}, 1992$, p. 1289-904.

3 Londe S. Causes of hypertension in the young. Pediatr Clin Nurth Am 1978; 25:55-65.

4 Hiner LB, Falker B. Renovascular hypertension in children. Pediatr Clin North Am 1993; 40:123-39.

5 Olson DL, Licberman E. Renalhypertension in children. Pediatr Clin North Am 1976; 23:795-805.

6 Robson AM. Special diagıustic studies for the detection of renal and renovascular forms of hypertension. Pediatr Clin North Ani 1978; 25:93.8.

7 James JA. Renal disease in childhurod. 2nd ed. Saint Louis: The CV MosbyCo, 1972. p.41-7, 259-62.

8 Bricket LT. Hypertension. In: Oski FA, Feigin RD, De Angelis $C D$, editors. Principles and practices of pediatrics. 2nded. Philadelphia: Lippincotr Co, 1994. p. 1088-92.

9 Scharer K. Renal hypertension in childhood. Annales Nestle 1984; $42: 1-18$. 